\title{
An insect wing discovered in the Early Permian Taiyuan Formation (Shanxi Province, China)
}

\author{
Jin Wang ${ }^{1}$, Olivier Béthoux ${ }^{2}$, Dong Ren ${ }^{3}$, and Yingying Cui ${ }^{4}$ \\ ${ }^{1}$ Shanxi Museum of Geology, Taiyuan, China \\ ${ }^{2}$ CR2P (Centre de Recherche en Paléontologie - Paris), MNHN - CNRS - Sorbonne Université, \\ 57 rue Cuvier, CP38, 75005, Paris, France \\ ${ }^{3}$ College of Life Sciences, Capital Normal University, Beijing, China \\ ${ }^{4}$ College of Life Sciences, South China Normal University, Guangzhou, China
}

Correspondence: Yingying Cui (cuiying19860105@gmail.com)

Received: 25 June 2019 - Revised: 21 August 2019 - Accepted: 22 August 2019 - Published: 13 September 2019

\begin{abstract}
The first discovery of an insect wing from the Taiyuan Formation, near Yangquan City, Shanxi Province, China, is described. The combination of its wing venation characters makes it difficult to assign it to any known major Paleozoic group. The comparison is made among the new material, stem-Orthoptera species, and "fossil Grylloblattodea". Further investigation on fossil insects from this locality is needed.
\end{abstract}

\section{Introduction}

The Taiyuan Formation (near Yangquan City, Shanxi Province, China) is composed of a group of deposits of continental-oceanic interaction facies, consisting of sandstone, dark grey shale (mudstone), limestone and coal, and is considered to be the Late Pennsylvanian to Early Permian age for the whole Taiyuan Formation (Wu, 1995; Wang, 2010). The remains of a fossil insect wing were recovered recently in the middle part of the Taiyuan Formation. According to the study of the fossil plants, brachiopods, gastropods, corals, crinoids, fusulinids and ostracods (Ge et al., 1985; Gao, 1988; Fan et al., 1999; Wan et al., 2017; Zhang, 2017), the fossil horizon is of Asselian age (Early Permian). Herein we provide a description of the insect remains.

\section{Material and methods}

The specimen (SXMG IV 0479 and SXMG IV 0480, part and counter-part, respectively) is housed at the Shanxi Mu-

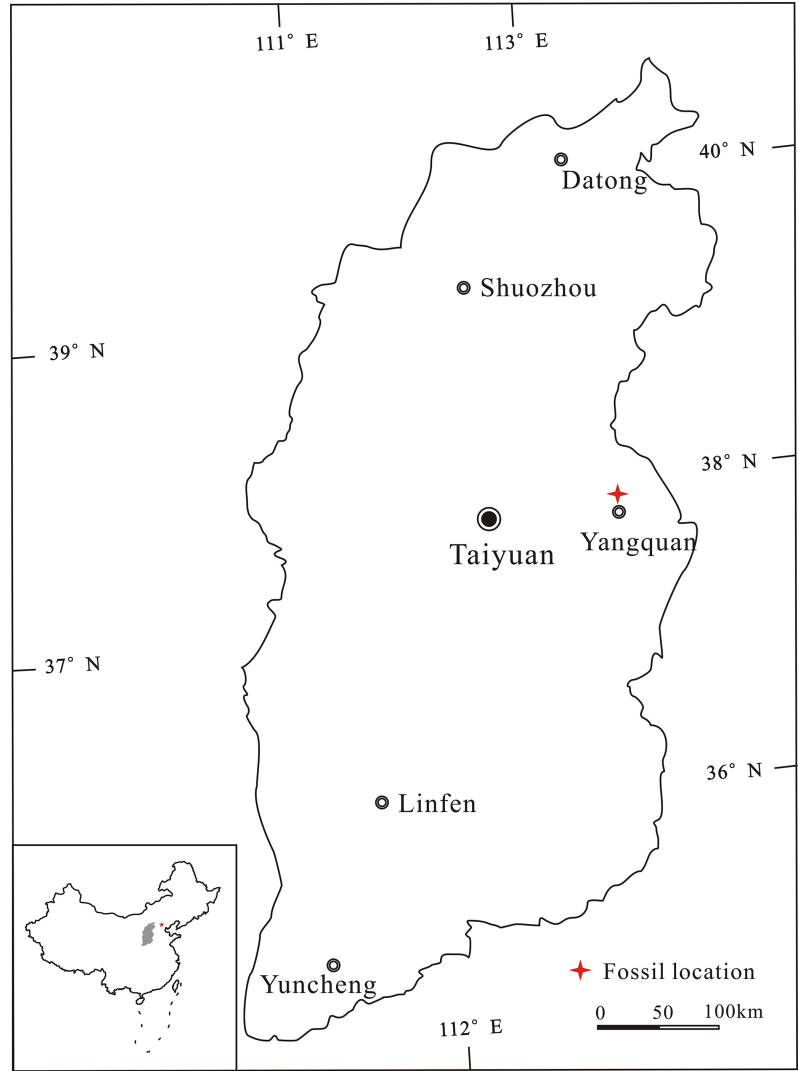

Figure 1. Locality of the insect fossil near Yangquan City, Shanxi Province, China. 

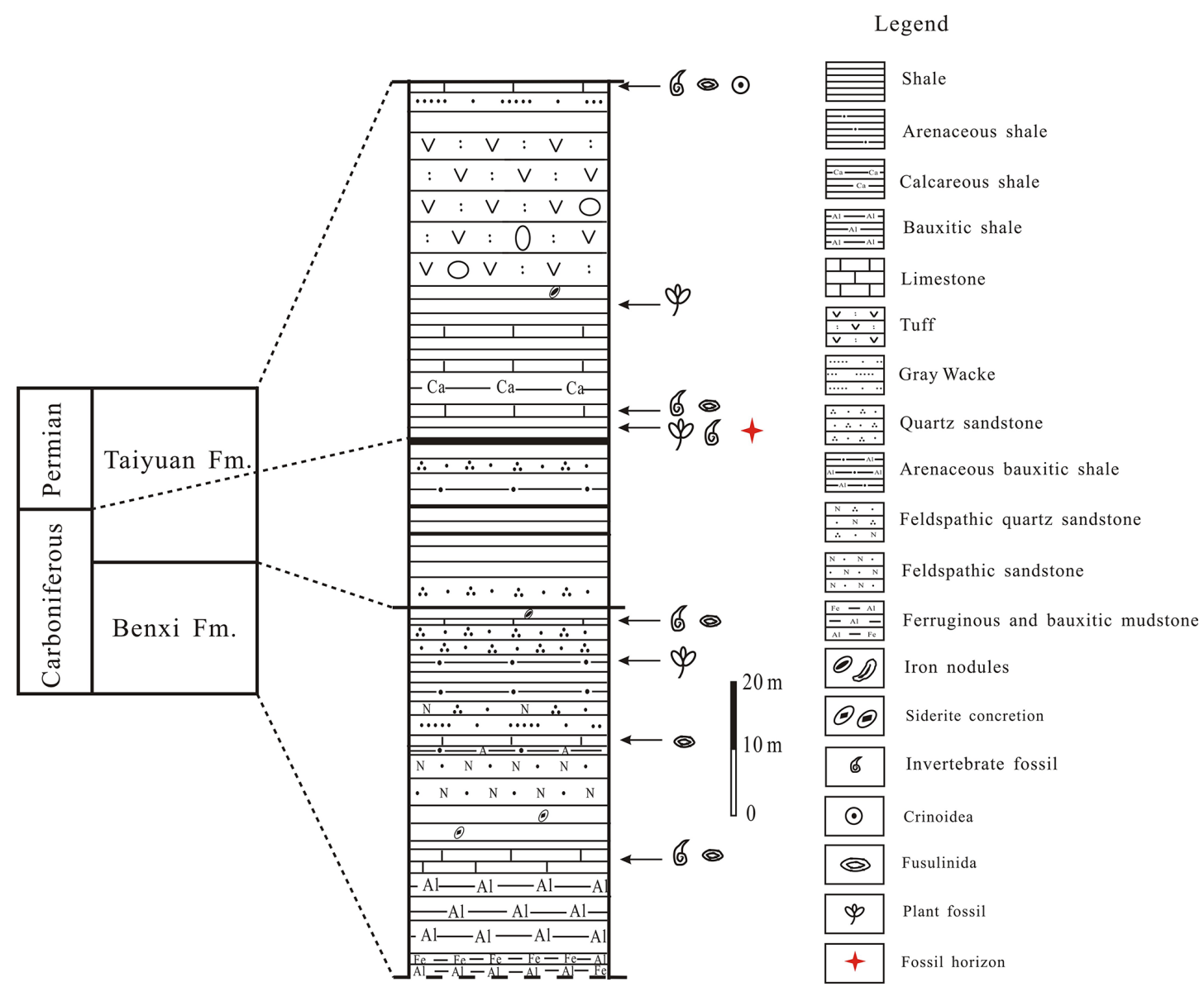

Figure 2. The stratigraphic column of the Taiyuan Formation, near Yangquan City, Shanxi Province, China. The arrow indicates the fossil horizon.

seum of Geology. It was examined using a Leica M165C microscope, and a handmade draft drawing was prepared with the aid of a drawing tube, under dry conditions (the specimen might be damaged by ethanol immersion). A photograph was taken using a Canon EOS 70D digital camera (Cannon, Tokyo, Japan) coupled to a Canon MP-E $65 \mathrm{~mm}$ macro lens and was optimized using Adobe Photoshop CC. The final drawing was performed using Adobe Illustrator CC (Adobe systems, San Jose, CA, USA), with the help of both the handmade draft drawing and optimized photograph.

In the context of the serial insect wing pattern (Lameere, 1922, 1923), we resort to homologies proposed by Béthoux and Nel (2002) for Orthoptera and their stem-relatives, as follows: ScP, posterior subcosta; RA, anterior radius; RP, posterior radius; MA, anterior media; MP, posterior media; $\mathrm{CuA}$, anterior cubitus; $\mathrm{CuP}$, posterior cubitus; $\mathrm{CuPa}$, anterior branch of CuP. Note that we discuss an alternative interpretation of the wing venation of the specimen that does not imply that it is a stem-Orthoptera. The adopted terminology applies.

\section{Systematic descriptions}

Class Insecta Linnaeus, 1758

Infraclass Neoptera Martynov, 1923

Order incertae sedis

Specimen SXMG IV 0479 and SXMG IV 0480: positive and negative imprints of a right wing (presumably forewing), basal part, posterior and distal parts missing; preserved part $12.9 \mathrm{~mm}$ long, $6.6 \mathrm{~mm}$ wide; anterior wing margin partly visible; only the very distal part of ScP visible, reaching anterior wing margin; RA very strong, emitting few anterior veinlets; RP forked shortly before the end of ScP, posteriorly pectinate, with three branches (anterior-most branch arising obliquely); area between RA and RP broad, with the broadest part $1.3 \mathrm{~mm}$ wide; $2-3$ rows of cells in the area between RA and RP basal to second fork of RP (then, single row of cells); $M$ neither clearly concave nor desclerotized, forked earlier than RP, with 3 (4?) preserved branches; $\mathrm{CuA}+\mathrm{CuPa}$ with five strongly preserved branches; except for the RA-RP area, inter-venal areas with a single row of cells (occasionally with 
(a)
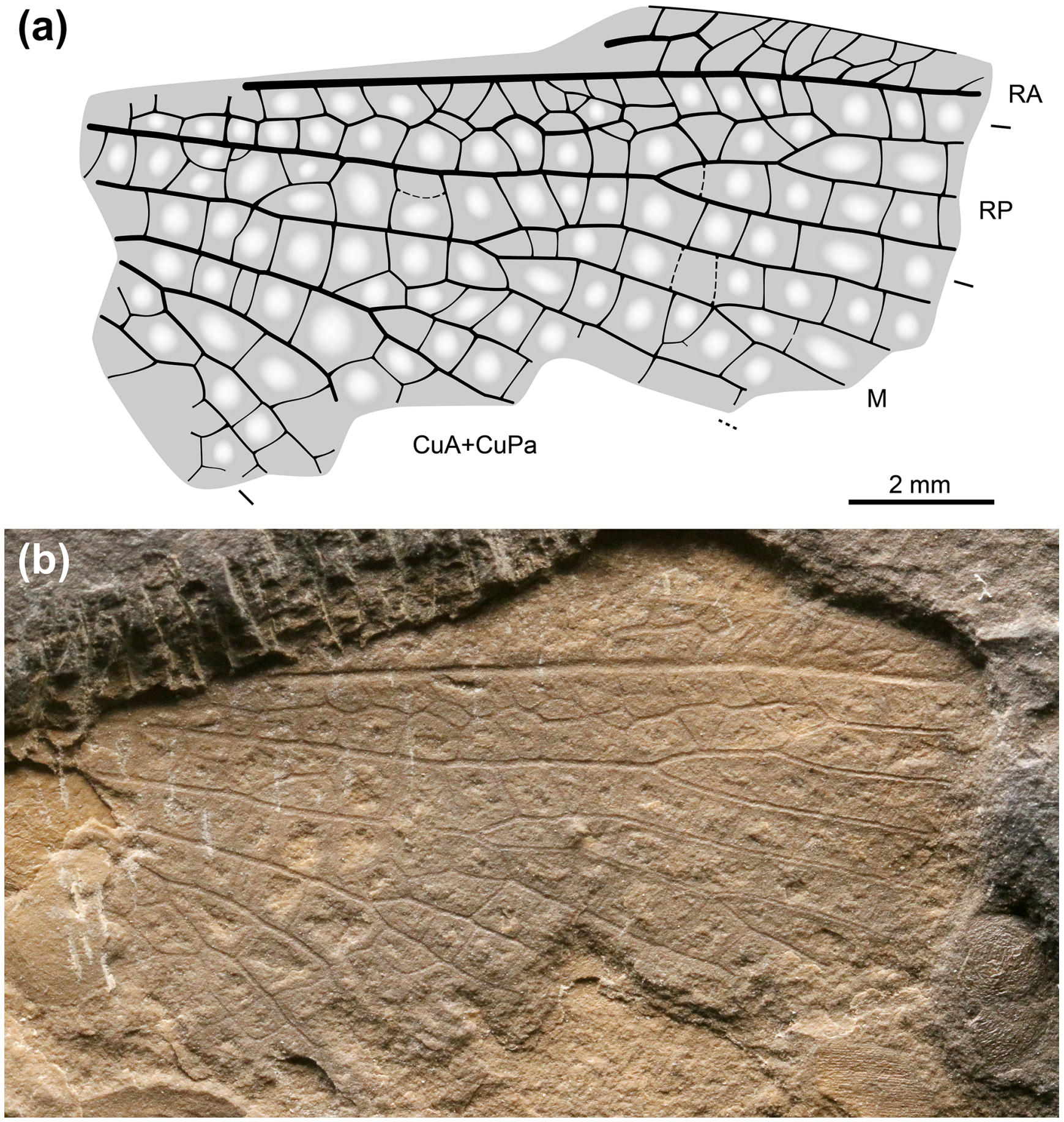

Figure 3. Putative stem-Orthoptera from the Taiyuan Formation (SXMG IV 0480): (a) interpretative drawing (see text for alternative interpretation) and (b) photograph (flipped horizontally).

reticulations); center of individual cells split unevenly, indicating lack of pigmentation (and, conversely, the presence of pigmentation in the remaining areas).

\section{Discussion}

Because of its incompleteness and its unusual combination of character states, the new specimen remains difficult to assign to any of the major groups of Paleozoic insects. The very long $\mathrm{RP}$ is an unusual feature which can be found in some stem- 
Orthoptera but also in the so-called "fossil Grylloblattodea". Among the former, Cacurgus spilopterus Handlirsch (1911) (see revision by Béthoux, 2006) also possess a very long stem of $\mathrm{M}$, which one can recognize in the specimen. The remaining, more posteriorly located branches would then belong to $\mathrm{CuA}+\mathrm{CuPa}$. This proposal, however, is challenged by the respective ages of $C$. spilopterus (Pennsylvanian) and of the locality (early Permian).

It remains possible to interpret all visible branches posterior to RP as belonging to MA and MP, in which case M is forked more basally than under the previous interpretation. We are not aware of a stem-Orthoptera displaying such a long RP stem in conjunction with a basal MA/MP fork. This combination is known in several "fossil Grylloblattodea", such as representatives of the family Ideliidae (Storozhenko, 1998; Aristov, 2002), know from various Permian localities. However, "Grylloblattodea" commonly possess a clearly concave and desclerotized MP, traits which none of the preserved veins display. Moreover, $\mathrm{CuA}$ is usually abundantly branched in this group, and it is not evident whether the wing could accommodate this system.

Hopefully this discovery will prompt further investigation in the corresponding locality, which might provide useful data on the actual affinities of the current specimen.

Data availability. The new material included in the paper is accessible and deposited in the Shanxi Museum of Geology, Taiyuan, China, and all data are included in the description.

Author contributions. JW and DR collected the material and contributed to the geological section; OB and YC prepared the paper and contributed to the editing.

Competing interests. The authors declare that they have no conflict of interest.

Acknowledgements. We thank the two anonymous reviewers for their review of the manuscript, and we also thank Editor-in-Chief Florian Witzmann for his kind help. The authors are grateful to Zhilu Tang, Suozhu Wang, Shichao Xu and Zhijun Bai for discovering and collecting the specimens.

Financial support. This research has been supported by the National Natural Science Foundation of China (grant nos. 31730087, 41688103 and 31900342), the Program for Changjiang Scholars and Innovative Research Team in University (grant no. IRT-17R75), the Support Project of High-level Teachers in Beijing Municipal Universities (grant no. IDHT20180518), and the Natural Science Foundation of Guangdong Province (grant no. 2018A030313130).
Review statement. This paper was edited by Florian Witzmann and reviewed by two anonymous referees.

\section{References}

Aristov, D. S.: Grylloblattids of the family Ideliidae (Insecta: Grylloblattida) from the Lower Permian of the Ural Mountains, Paleontol. J., 36, 44-47, 2002.

Béthoux, O.: Revision of Cacurgus Handlirsch, 1911, a basal Pennsylvanian Archaeorthoptera (Insecta: Neoptera), B. Peabody Mus. Nat. Hi., 47, 29-35, 2006.

Béthoux, O. and Nel, A.: Venation pattern and revision of Orthoptera sensu nov. and sister groups, Phylogeny of Palaeozoic and Mesozoic Orthoptera sensu nov., Zootaxa, 96, 1-88, 2002.

Fan, B. H., Zhu, W. B., and He, X. L.: Early Early Permian brachiopod fauna from Yangquan, Shanxi Province, Acta Palaeontol. Sin., 38, 353-364, 1999.

Gao, J. H.: The Paleoecological features and environment background of brachiopod from the Taiyuan formation in Shanxi Province, Geoscience, 2, 175-185, 1988.

Ge, B. X., Yiu, G. X., and Li, Ch. Sh.: A Preliminary study on sedimentary environments and law of coal- bearing formation in Yangquan, Shanxi, Acta Sedimentol. Sin., 3, 33-44, 1985.

Handlirsch, A.: New Paleozoic insects from the vicinity of Mazon Creek, Illinois, Am. J. Sci., 31, 297-326, 353-377, 1911.

Lameere, A.: Sur la nervation alaire des Insectes, B. Cl. Sci. Ac. Roy. Bel., 8, 138-149, 1922.

Lameere, A.: On the wing-venation of insects, Psyche, 30, 123-132, 1923.

Linnaeus, C.: Systema naturæ per regna tria naturæ, secundum classes, ordines, genera, species, cum characteribus, differentiis, synonymis, locis, Stockholm, 824 pp., 1758.

Martynov, A. V.: On two basic types of insect wings and their significance for the general classification of insects, in: Trudy Pervovo Vserossijskovo S'exda Zoologov, Anatomov i Gistologov, edited by: Deryugina, K. M., Nauka, Moscow, Russia, 88-89, 1923.

Storozhenko, S. Y.: Sistematika, filogeniya i evolyutsiya grilloblattidovykh nasekomykh (Insecta: Grylloblattida), Dal'nauka, Vladivostok, 207 pp., 1998.

Wan, M. L., Yang, W., He, X. Zh, Liu, L. J., and Wang, J.: First record of fossil basidiomycete clamp connections in cordaitalean stems from the Asselian-Sakmarian (lower Permian) of Shanxi Province, North China, Palaeogeogr. Palaeocl., 466, 353-360, 2017.

Wang, J.: Late Paleozoic macrofloral assemblages from Weibei Coalfield, with reference to vegetational change through the Late Paleozoic Ice-age in the North China Block, Int. J. Coal Geol., 83, 292-317, 2010.

Wu, X. Y.: Carboniferous floras, in: Fossil Floras of China Through the Geological Ages, edited by: Li, X. X., Zhou, Z. Y., Cai, C. Y., Sun, G., Ouyang, S., and Deng, L. H., Guangdong Science and Technology Press, 58-93, 1995.

Zhang, H. X.: The late Paleozoic brachiopod communities and their environmental significance from Shuiquangou, Yangquan, Shanxi Province, Inner Mongolia Sci. Technol. \& Econ., 1, 7576, 2017. 